\title{
Justification for Entrepreneurial Education and Attendant Challenges in Bamidele Olumilua University of Education, Science and Technology Ikere
}

\author{
Fayigbe, $\mathrm{G}^{1} \quad$ Ogunleye, W.A ${ }^{2}$ \\ 1.Department of Entrepreneurial Studies, Bamidele Olumilua University of Education, Science and Technology, \\ Ikere-Ekiti, Ekiti State \\ 2.Department of Vocational and Technical Education, Faculty of Education, Ekiti State University, Ado Ekiti,
} Ekiti State

\begin{abstract}
The paper examined justification for Entrepreneurial Education and attendant challenges in Bamidele Olumilua University of Education, Science and Technology Ikere. The paper revealed that Entrepreneurial Department was created to produce graduates who will act naturally dependent, job creators, and not job seekers in Nigeria. Towards achieving the objectives of entrepreneurial studies, the paper highlighted factors that need to be put in place such as employment of qualified lecturers, adequate funding, a workshop/exhibition center, adequatefacilities, equipment, and instructional materials for teaching and learning. The paper concluded that the Department of Entrepreneurial Studies needs adequate provision of all the factors identified in the paper to achieve the purpose of creating the Department. For smooth running of Entrepreneurship Studies and to guarantee an expected outcome, the paper suggested that Government and the non-government agencies should collaborate to provide an enabling environment for effective teaching and learning of Entrepreneurial Studies in the institution, also Government and other relevant authorities should establish an Entrepreneurship Development center with all the necessary facilities needed for Entrepreneurial Studies in the University.
\end{abstract}

Keywords: Entrepreneurial Skills, Job Creation, Adequate Fund, Proper Implementation

DOI: $10.7176 / \mathrm{JEP} / 12-14-07$

Publication date:May $31^{\text {st }} 2021$

\section{Introduction}

Entrepreneurial Studies is an intervention program that cannot be over-emphasized in this dispensation. The Federal Government introduced the program into tertiary institutions education in Nigeria to equip graduates/students with entrepreneurial skills to make them employable and/or become employers of labor in the society. In Nigeria, Entrepreneurial study was introduced into tertiary education in 2006 effective from 2007/2008 academic sessions to prepare students for self-reliance and discourage graduates from craving for non-existent white-collar jobs and to sustain an economy of high-level unemployment reduction (Adekanmbi \& Ogunleye, 2019). This was part of the efforts of the Federal Government of Nigeria to reduce unemployment in the country. An entrepreneurial study was made compulsory in Nigerian universities to create a positive entrepreneurial mindset in students for their benefit and the society at large. Hence, there is need for creation of Entrepreneurial Studies Department in Bamidele Olumilua University of Education, Science, and Technology Ikere Ekiti BOUESTI.

Generally, entrepreneurial studies provides an avenue for graduates to contribute to the economy by creating new enterprises and new economic sectors that will generate jobs for them and others to end the myriad of problems and realities of unemployment in Nigeria. It is another means to inculcate self-employment entrepreneurship culture in students of tertiary institutions. Also, to recognize Entrepreneurship studies as a course in universities, Aja-Okorie and Adali (2013) revealed that National Universities Commission (NUC, 2004) was given a mandate by Federal Government to include entrepreneurial studies curriculum in the Nigerian Universities education for the hope of reducing unemployment among fresh graduates. Entrepreneurship education is a kind of education that cultivates the comprehensive qualities of entrepreneurship, the value of innovative spirit, and entrepreneurship abilities (Jianping \& Chao, 2010).

According to Li Jianping and Wei Chao (2010), the general objectives of entrepreneurship education in universities are:

1. To cultivate the spirit of entrepreneurship in students. It is the conception and ideology of starting a career, the spiritual state of self-reliance, hard struggle, achievements, and contributions.

2. Strengthening three kinds of professional qualities: Entrepreneurship education needs students to exercise and to improve professional qualities and abilities in all aspects in the course of study and practice to strengthen the following;

$>$ Leadership: this is the ability to take full advantage of human resources and objective conditions within the jurisdiction to reach maximum performance and achievement with optimal cost. 
$>$ Risk-taking: the ability of risk-taking is a fundamental quality of entrepreneurs, and

$>$ Teamwork: is the spirit of voluntary cooperation and cooperative efforts to achieve attain desired goals.

3. Bearing quality-oriented education: according to Jianping and Chao (2010) entrepreneurship education is a part of developing quality-oriented education and is the support and concrete reflection of quality-oriented education in tertiary institutions.

4. Expands ways of employment: Jobs available in the labor market for graduates today are limited compared to the numbers of graduates producing every year in tertiary institutions. The development of entrepreneurship education in tertiary institutions as a result of the high rate of unemployment among graduates to instill skills needed to create small business

\section{Philosophy of Entrepreneurial Programme in BOUESTI}

The philosophy of the Bachelor of Science programme in Entrepreneurial Studies is the development of a breed of achievers, innovators and entrepreneurs who will provide the leadership in the development of the Nigerian economy and shoulder the responsibility of transforming the mindset of Nigerian youths through teaching, training and consultancy for the development of a national culture of enterprise and productivity (Handbook, 2020).

\section{Objectives of Entrepreneurial Programme in BOUESTI}

The major objectives of the degree programme in entrepreneurial are as follows:

i. To develop a group of competent professionals in the field ofentrepreneurship who will be responsible for transforming themindset of Nigerian youths towards enterprise and innovation.

ii. To motivate our youths through the psychological empowerment obtainable from entrepreneurship training.

iii. To equip Nigerian youths with skills and competencies in venture opportunity identification,feasibility assessment, business plan development, venture creation and new venturemanagement.

iv. To instill in our youths the capacity for independent thought, economic freedom andcreativity.

v. To imbibe in our younger generations a greater magnitude of the urge to achieve, excel andcompete, through honest and meaningful ventures that add value to national and societal wellbeing (Handbook, 2020).

\section{Current State of Entrepreneurial Studies in BOUESTI}

Entrepreneurial studies department is a new department in the Bamidele Olumilua University of Education, Sciences, and Technology Ikere Ekiti. The Department created opportunities for the training of their students in practical entrepreneurial skills for them to become self-reliant and prepare for a future that will, in turn, eliminate the economy of miscreants in Nigeria. Also, relevant skills for employment are to be imparted to students in a practical oriented than theoretical because it was mainly created to reduce millions of graduates annually turned out into an economy that is already overpopulated with the unemployed. Nwanaka and Amaehule (2011) supported that possession of skills is vital in preventing graduates from becoming social misfits because skilled persons become gainfully employed through entrepreneurship education.

Despite that the Entrepreneurial Studies curriculum is designed to impact skills and knowledge both in theory and practical in graduates of Bamidele Olumilua University of Education, Sciences, and Technology Ikere Ekiti, there are still many problems to be solved before the program takes off. These problems include inappropriate placement of the Entrepreneurial Studies Department under the school of Technology instead of the school of science where students would be awards a Bachelor of Science certificate when they graduate. Also, the shortage of entrepreneurship personnel is another problem, lack of workshop center for practical, no instructional materials, inadequate conducive lecture rooms, and inadequate infrastructures. The stated above is the current state of Entrepreneurial Studies Department in the BOUESTI that require attention before its commencement.

\section{Goals of the Entrepreneurial Studies Department in BOUESTI}

In this dispensation, possession of certificates is not the only remedy to the problem of unemployment because it no longer guarantees the employment of graduates in the society we found ourselves today rather than the development of entrepreneurial skills could help students to identify and take advantage of the numerous business opportunities around them. Entrepreneurial Studies Department in BOUESTI is a program designed to impact students crucial life skills that will help them navigate the uncertain future. These skills include problemsolving, teamwork, empathy, as well as learning how to develop and grow business. Furthermore, the department offer functional education to students that would make them self-employed and self-reliant, providing adequate training for students to be creative and innovative in identifying novel business opportunities and establish a career in small and medium scale businesses and creation of employment that will serve as a catalyst for 
economic growth and development. The goal of the Department of Entrepreneurship Studies in BOUESTI is to continuously foster an entrepreneurial culture among students and teach them to develop skills that would support them in establishing and maintaining sustainable business ventures. This is in line with Bassey and Archibong (2005) that the goal of entrepreneurial studies in is to empower graduates irrespective of their areas of specialization with skills that will enable them to engage in income yielding venture, if they are unable to secure jobs in the public sector.

\section{Teaching and Learning of Entrepreneurial Studies}

Teaching and learning of Entrepreneurial Studies designed to be theoretical and practical oriented in BOUESTI. The theoretical aspect will be treated in the lecture rooms while the practical aspect will be taking in the entrepreneurship center in the institution and other accredited centers for learning in order to achieve better results. These methods are basically meant to inculcate the skills and knowledge that will assist students to be self-reliant according to Sahlberg, (2010) who opined that the pedagogical approaches adopted in entrepreneurship education should create a shared vision in students to see socio-economic problems as challenges that could be translated into viable and feasible business opportunities. In addition, to stimulate an individual's interest to perform as an entrepreneur; hence teaching methods in entrepreneurial studies should enable tryouts through business startups in an organized environment within Universities (Ahmad, Baharun, \& AbdRahman, 2004).

\section{Current Needs in Department of Entrepreneurial Studies in BOUESTI}

The following are the needs of the Entrepreneurial Studies department in BOUESTI for effective implementation;

Employment of Qualified Lecturers: Presently the department needs more competent and skilled academic staff to teach Entrepreneurial Students. Competency is needed in teaching entrepreneurship students. Olokundun (2017) supported that the competence of an educator cannot be overemphasized particularly because practical business skills and experience are required to inculcate entrepreneurial skills in students.

ii. $\quad$ Provision of Adequate Fund: Department of Entrepreneurial studies is still at the elementary stage in BOUESTI, adequate fund is another current need for the take off of the program. To achieve the objectives of entrepreneurial studies a huge amount of money is required. Funding for entrepreneurial courses would increase the entrepreneurial desires of students and also enhance the capacity-building of entrepreneurship lecturers.

iii. Appropriate placement of Entrepreneurial Studies Department under the School of Sciences: It is necessary to make adequate provisions and appropriate adjustment of the position of Entrepreneurial Departments before the program will finally take off. Entrepreneurial Studies should be under the School of Science because it is a social science-oriented course.

iv. Establishment of Entrepreneurial Exhibition/Workshop Centre: To foster the practice of entrepreneurship, incubation centers are needed to be established in the institution because they are vital aids to innovation and idea generation. It would provide students with practical platforms and chances and make them improve and exercise various kinds of qualities and abilities of entrepreneurs in the workshops (Jianping \& Chao, 2010).

v. Adequate facilities and equipment for teaching and learning: For effective teaching and learning, adequate facilities are very essential because Entrepreneurial Studies is an imperative that would make a positive contribution to improving the entrepreneurship orientation of people, leading to the acquisition of skills, creativity, confidence, drive, and courage, in order to create employment for self and other (Ekpoh \& Edet, 2011).

\section{Conclusion}

The paper examined the justification for Entrepreneurial Education and attendant challenges in BOUESTI and having critically looked at the state and needs of the Department of Entrepreneurial Studies. It was discovered that inadequate funds, shortage of personnel, workshop center for practical, equipment and instructional materials, and inadequate infrastructures are factors that could affects the implementation of the programme. Therefore, the paper concluded that the Department of Entrepreneurial Studies needs adequate provision of all the factors identified in the paper to achieve the purpose of creating the Department. This would help to equip students with the needed skills, and knowledge that will make them have ability to identify, screen, and grab available opportunities in their environment to start and sustain their private business thereby solving problems of unemployment.

\section{Suggestions}

Based on the critical reviewed of the current state and needs for effective implementation of Entrepreneurial 
Studies in BOUESTI. Hence, the following suggestions were made in order to achieve the planned goals of establishing the Entrepreneurial Studies:

1. The government and the non-government agencies should collaborate to provide an enabling environment for effective teaching and learning of entrepreneurial studies in the institution to guarantee an expected outcome

2. The government and other relevant authorities should establish an Entrepreneurial Development center with all the necessary facilities needed for entrepreneurship studies in the universities.

3. The government should support the management by providing substantial funds to kick start the Department of Entrepreneurial Studies. Also, the welfare of the staff who delivers entrepreneurial studies should be a priority.

4. For graduates of entrepreneurial studies to set up their business with pioneering aptitudes gained in the school, sufficient funds should be put aside by both the public authority and non-government in Nigeria to help them.

5. The management of BOUESTI should employ qualified entrepreneurship educators to teach entrepreneurial studies in BOUESTI to help students learn entrepreneurial skills. Also, authorities of the institution should ensure that lecturers assigned for teaching entrepreneurship education courses are specialists in the field.

6. The perception of students enrolling for entrepreneurial studies should be towards job creation for themselves and others since they would be skillful in a particular trade of interest.

\section{References}

Adekanmbi, J.A. \& Ogunleye, W.A. (2019). Overview of challenges confronting the entrepreneurship development in Nigeria. Proceedings of the 15thiSTEAMS Research Nexus Conference, Chrisland University, Abeokuta, Nigeria, 16th - 18th April, 2019.67-72. Available online at www.isteams.net.DOI Affix - https://doi.org/ 10.22624/AIMS/iSTEAMS-2019/V15N1P7

Ahmad, F.S.H., Baharun, R. \& AbdRahman, S.H (2004). Interest in entrepreneurship: an exploratory study on engineering and technical students in entrepreneurship education and choosing entrepreneurship as a career. RMC project, Faculty of Management and Human Resource Development Universiti Teknologi Malaysia

Aja-Okorie, U. \& Adali, O. (2013). Achieving youth empowerment through repositioning entrepreneurial education in Nigerian Universities: problems and prospects.European Scientific Journal, 3(.9), 2-8

Bassey, U.U. \& Archibong, I.A. (2005). Assuring quality graduate output through entrepreneurial oriented education in Nigerian Universities.Nigerian Journal of Curriculum Studies, 12(3), 18-23.

Handbook, (2020) Unpublished Bamidele Olumilua University of Education, Sciences, and Technology Ikere Ekiti

Ekpoh, U.I., \& Edet, A. O., (2011). Entrepreneurship Education and career intentions of tertiary education Students in Akwalbomand Cross River States, Nigeria.International Education Studies 4(1),172-178

Jiangping, L. \& Chao, W. (2010). "Objectives and approaches of Entrepreneurship Education in Chinese Colleges and Universities."Proceeding of the 7th International Conference on Innovation \& Management 2010. $1824-1827$

National University Commission (2004). Labour market expectations of Nigerian graduates. Abuja: Education Trust Fund (ETF)

Nwanaka, C. R. \& Amaehule, S. (2011). Skills acquisition: imperative for business studies educators among secondary schools in Rivers State. Mediterranean Journal of Sciences. 2(7), 37-43.

Olokundun, M.A. (2017). Perceptions of students on entrepreneurship education and entrepreneurial intentions in selected Nigerian universities. Unpublished thesis Department of Business Management, College of Business and Social Sciences, Covenant University, Ota, Ogun State.

Sahlberg, P. (2010). Rethinking accountability in a knowledge society. Journal of Educational Change. 11(1), 45-61. 